\title{
Integrated Education, Intergroup Relations, and Political Identities in Northern Ireland
}

\author{
Bernadette C. Hayes, University of Aberdeen \\ Ian McAllister, Australian National University \\ Lizanne Dowds, University of Ulster
}

\begin{abstract}
Education is often seen as a means of achieving social change. Underlying this view is contact theory, which argues that increased contact between social groups will help reduce prejudicial attitudes and alleviate racial and ethnic divisions. This article tests and extends these propositions by examining the long-term impact of segregated and integrated education on political identities and attitudes. Using a pooled sample of surveys conducted on the adult population in Northern Ireland between 1998 and 2003, we address, for the first time, the question of whether or not experiencing a religiously integrated education has a significant effect on the political outlooks of Protestants and Catholics. The results suggest that attendance at a religiously integrated schooleither one formally constituted as integrated or a religious school incorporating a proportion from the opposite religion-has positive long-term benefits in promoting a less sectarian stance on national identity and constitutional preferences. The results also support recent research that has shown that the impact of contact on intergroup relations may not only vary significantly in terms of the nature of the contact situation but also in terms of the societal status of the groups involved. We conclude that as the numbers experiencing integrated schooling grows, these individuals have the potential to create a new common ground in Northern Ireland politics. Keywords: integrated education, social contact, intergroup relations, identity, Northern Ireland.
\end{abstract}

Education has traditionally been seen as an institution that reflects the social differences that exist in society, and which are reproduced from generation to generation through socialization. A more recent view is that education has the capacity to create social change by identifying the sources of conflict and developing policies to ameliorate them. This was the case in the United States where the landmark decision of Brown v. Board of Education (1954) heralded a new era in educational policy. Declaring racially segregated schools to be unconstitutional, the U.S. Supreme Court decision triggered a shift in the social role of education; schools came to be regarded as institutions with the potential to improve racial and ethnic group relations by diversifying students' social networks and thereby reducing prejudice (see Zirkel and Cantor 2004). In addition to improving students' life chances, it was believed that interracial contact would lead to a lessening of racist attitudes among whites and, ultimately, to more integration in other aspects of society (Brown v. Board of Education 1954:494).

These diverging views about the role of education also came into sharp relief in Northern Ireland when the civil disturbances began in 1968, with the segregated school system becoming a source of concern for many educators and community activists. An increasing number

The authors wish to thank Paula Devine for providing them with the combined data set. They would also like to thank the anonymous referees and Social Problems editor Amy S. Wharton and associate editor Lisa Catanzarite for their helpful and constructive comments, and Joanne Hughes and Caitlin Donnelly for providing them with related unpublished material. Direct correspondence to: Bernadette C. Hayes, Department of Sociology, University of Aberdeen, Aberdeen AB24 3QY, Scotland. E-mail: b.hayes@abdn.ac.uk.

Social Problems, Vol. 54, Issue 4, pp. 454-482, ISSN 0037-7791, electronic ISSN 1533-8533. @ 2007 by Society for the Study of Social Problems, Inc. All rights reserved. Please direct all requests for permission to photocopy or reproduce article content through the University of California Press's Rights and Permissions website at www.ucpress- journals.com/reprintinfo/asp. DOI: $10.1525 / \mathrm{sp} .2007 .54 .4 .454$. 
of parents and teachers endorsed the view that schools should become involved directly in efforts to improve community relations via contact schemes and joint initiatives (see Darby 1976; Dunn 1986). Early academic research also supported this view (see Dunn, Darby, and Mullan 1991; Murray 1985). Highlighting the lack of contact between Protestant and Catholic schools, researchers identified the segregated educational system as a key contributory factor in perpetuating the conflict, although there was a dearth of empirical evidence to either support or reject the hypothesis. Despite the passage of nearly four decades and numerous policy initiatives, this lack of empirical investigation continues to this day, especially with regard to the long-term effects of integrated schooling (Abbott, Dunn, and Morgan 1998; McGlynn 2003).

This article examines the impact of segregated and integrated education on political attitudes in Northern Ireland. More specifically, using contact theory as our frame of reference, we address the question of whether or not integrated education has a long-term and significant effect on the identities and constitutional preferences of the adult population in Northern Ireland. Although since first articulated by R. Williams (1947) and later refined by Gordon Allport (1954), contact theory has provided the focus for a plethora of studies in the United States and elsewhere on reducing racial and/or ethnic prejudice and tensions within a society, to date its contribution in terms of alleviating deeply-seated divisions in terms of national and political divisions, as are evident in Northern Ireland, has not been systematically assessed.

The first part of this article outlines the educational system in Northern Ireland and evaluates previous research findings concerning the relationship between integrated education and community relations between Protestants and Catholics within this society. Using contact theory as our frame of reference, we then suggest a number of hypotheses as to the impact of integrated education on political outlooks in Northern Ireland. Finally, we examine the nature and extent of integrated education among the adult population in Northern Ireland and investigate the consequences of exposure to the two differing educational systems-integrated versus segregated-on political outlooks. More specifically, using a pooled sample of surveys conducted on the adult population in Northern Ireland between 1998 and 2003 (ARK 1998-2003), we address, for the first time, the question of whether or not experiencing a religiously integrated education has a significant effect on the identity patterns and constitutional preferences of Protestants and Catholics within this society.

Although educational segregation based on religion is not unique to Northern Ireland, it has particular resonance there. Northern Ireland remains a deeply divided society; not only are Protestants and Catholics educated separately, but they are also segregated both residentially and in their workplaces, and display extremely low levels of religious mobility and intermarriage (Breen and Devine 1999; Breen and Hayes 1996; Hughes et al. 2006). Added to this separation are social inequalities. Despite the passage of a series of anti-discrimination laws since the late 1970s, Catholics remain, on average, less affluent than Protestants and are substantially more likely to be unemployed (see Russell 2004).

However, more so than any other factor it is differences in identity patterns and territorial allegiances that divide the two communities within this society. Preferences on these two issues are polarized around two competing ethnonational identities: those who identify themselves as British and wish to retain the union between Northern Ireland and Great Britain versus those who identify themselves as Irish and wish to see the two parts of the island of Ireland united. As John McGarry and Brendan O'Leary (1995) put it: “the crucial endogenous cause of the conflict has been the presence of two competitive ethnonationalist communities within the same territory" (p. 356). The conflict is further heightened in that the political cleavage seems to coincide exactly with the religious division between Protestants and Catholics. Contemporary explanations of the conflict suggest that it is differences in these religiously-based ethnonationalist identities-British Protestants who wish Northern Ireland to remain part of the United Kingdom versus Irish Catholics who desire the reunification of the island of Ireland-which gives Northern Ireland politics its distinctive character and has 
resulted in the deaths of more than 3,000 people since 1969 (see Hayes and McAllister 2001; McGarry and O'Leary 1995).

This is not to deny, however, some important variation in national identity and constitutional preferences, particularly within the Catholic community. Although Protestant identity patterns and constitutional preferences have become increasingly homogeneous since the outbreak of the current troubles in 1968, ${ }^{1}$ Catholic identity patterns remain more divided. ${ }^{2}$ Furthermore, there is some evidence to suggest that among those Protestants and Catholics who wish to disavow traditional allegiances within their own communities, the most attractive and acceptable badge of identity is the more neutral "Northern Irish" label. ${ }^{3}$ However, for the vast majority of individuals, their religious and political identities remain coterminous. It is for this reason-its conjunction with sociopolitical divisions within the wider society-that educational segregation on the basis of religious denomination remains a crucial issue in Northern Ireland (Dunn and Morgan 1991). In fact, for many people, their first contact with a member of the opposing religious tradition and culture may not be until they attend university or enter the workforce.

\section{Religion and Education in Northern Ireland}

Since its foundation in 1921, Northern Ireland has had two separate, religiously based educational systems at both the primary and secondary level. The state (i.e., "controlled") system is attended by Protestants, with a number of voluntary grammar schools also attended predominantly by Protestants. ${ }^{4}$ Catholics attend schools that are all voluntary (as opposed to state controlled) and, although also state financed, are operated by the Catholic Church and commonly known as the maintained sector. This bipartite system long predates the present

1. In 1968, just before the current phase of the troubles, less than two-fifths of Protestants identified themselves as British, a fifth saw themselves as Irish, and a third claimed an Ulster identity. After three decades of the troubles, Protestants had swung most definitely to adopting a British label: In 1989, with the introduction of a "Northern Irish" identity as a response category in survey questionnaires, 68 percent of Protestants claimed a British identity and only 3 percent an Irish one, with one in ten claiming an Ulster identity and 16 percent a Northern Irish one. Since then, Protestants have remained strongly committed to a British identity with almost eight out of every ten Protestants seeing themselves as British and about 15 percent claiming a Northern Irish identity. Protestants also remain strongly committed to retaining the union with Britain; survey data suggests that around 90 percent of individuals have consistently supported this position throughout the various survey years (see Fahey, Hayes, and Sinnott 2006).

2. In 1968, 76 percent of Catholics identified themselves as Irish, a fifth saw themselves as British, and only 5 percent claimed an Ulster identity. By 1989, the number of Catholics choosing to describe themselves as either Irish or British had fallen in favor of a Northern Irish label; whereas 60 percent of Catholics identified themselves as Irish, 25 percent identified themselves as Northern Irish, and only 8 percent as British, a pattern which continues to this day. Catholics also remain more divided than Protestants in terms of their territorial allegiances, with around two-thirds of individuals supporting a united Ireland, about a fifth wishing to maintain the link with Britain, and one in ten supporting an independent Northern Ireland state (see Fahey et al. 2006).

3. According to Moxon-Browne (1991), the attractiveness of this Northern Irish label may be explained by its ambiguity. For Catholics, it does not legitimate political boundaries or compromise their aspirations as the term can refer to the geographically northern part of the island of Ireland. Similarly, the Northern Irish identity does not compromise the British identity of Protestants as the term can be seen as derived from Northern Ireland, an officially designated region of the United Kingdom. This is not the case, however, when an Ulster identity is considered, which despite its problematic geographical origins - to ensure a Protestant majority, the formation of the Northern Ireland in 1921 was based on only six of the nine countries of the historic province of Ulster-has been the exclusive and traditional choice of the Protestant community and long associated with Protestant domination (see Ruane and Todd 1996).

4. While all students attend primary schools from the age of five (sometimes a year earlier) through eleven, at the age of ten or eleven most students take a series of examinations (called the "selection procedure" or, popularly known as the Eleven Plus). Students who do well in the Eleven Plus enter grammar schools at the age of 11 or 12 where they receive an academically-orientated education until the age of 18 . Those who do not sit the examination or who do not do well in the Eleven Plus typically attend secondary intermediate schools where the curriculum is also educational but neither expressively academic nor vocational. Achieving a good grade in the Eleven Plus does not constitute an educational qualification in itself but enables a student to attend a grammar school. Attendance at grammar schools has always been much higher for children from middle class backgrounds. 
constitutional arrangements in Northern Ireland. Prior to partition, most schools were owned by church authorities. The first Education Act passed by the new Northern Ireland parliament in 1923 attempted to replace church schools with a single, unified, nondenominational system. The Act, however, was vehemently rejected by all churches, Protestant and Catholic. Church opposition to the proposed new system was so widespread that by 1930 the government was forced to establish a de facto segregated education system, a situation that continues to this day. ${ }^{5}$

Government statistics confirm the continuance of this religiously segregated education system (see DENI 2005). Based on the religious composition of school students in 2004-2005, the data show that while 93 percent of Protestant children attend a controlled or state school, the equivalent figure among Catholic children attending a Catholic-maintained school is 91 percent. There is also a small minority of students (2.8 percent in 2004-2005) who cross the religious divide and attend a segregated school different to their own religion, which may be considered a "religiously mixed" or informally integrated school. Furthermore, there is evidence to suggest that this crossover in attendance is more common among Catholics (4.4 percent in primary schools) than Protestants ( 1 percent in primary schools). The crossover is smaller in secondary schools but more marked in grammar schools: 0.7 percent of students in Catholic grammar schools are Protestant but 8.3 percent of pupils in Protestant-controlled grammar schools are Catholic. Thus, at least as far as the informally integrated educational sector is concerned, these schools are essentially Protestant schools with a minority of Catholic pupils in attendance.

In addition to their religious composition and management structure, the most obvious difference between the two educational systems is the curriculum. For the most part, children take different subjects, learn different religions, read different books, and most importantly, learn different histories (see Darby 1974; Darby et al. 1977; Magee 1970; Murray, 1985). A. M. Gallagher (1995) studied the subjects taken by a sample of school students attending different grammar schools. He found that the largest differences were in culturally specific subjects, with more Catholics taking religious education than Protestants, and Protestant students being more numerous than Catholics across most of the science subjects, notably biology and mathematics. There was also evidence to suggest that even when religious education was conducted, there was little attempt to deal with "the problems of comparative religion which lies at the root of so many problems in Northern Ireland, the Protestant-Catholic division" (Greer quoted in Gallagher 1995:26).

More than religious education, however, is the differences encountered in the teaching of history in Protestant and Catholic schools (Gallagher 2003:65-66). For decades Catholic children were taught Irish history, often with overtly political overtones. In many history books there was an obsession with the Anglo-Irish conflict and Sean Farren (1976) found in some a "justification for the nationalist cause in terms that could often be accused of bias and of a lack of proper historical perspective" (p. 29). By contrast, Protestant children were rarely taught about Irish history, except when it related to British history. While many of these biases have been addressed since the 1970s, most notably through the introduction of a common (though voluntary) curriculum in 1990, ${ }^{6}$ it still remains the case that a Catholic is likely to study more Irish history than a Protestant, and a Protestant will study more British history than a Catholic.

5. Crucial components of the 1930 Education Act were the management of voluntary schools, which was broadened to include the clergy and their funding, half of which now came from the state. This discrepancy in funding was partially removed in 1968 but it was not until the early 1990s that the discrepancy in capital funding was finally eliminated (see McGrath 2000, for a detailed and historical discussion of this issue).

6. This is not to deny, however, the continuing importance of the "school ethos" or differences in relation to the "hidden curriculum." For example, it is still the case that whereas assemblies in Protestant schools often involve singing traditional Protestant hymns and wreaths are laid in Remembrance Day services, Catholic schools concentrate on Irish historical commemorations (such as Saint Patrick's Day) and Catholic religious rituals. 
A distinctively different picture emerges when the integrated educational sector is considered. In fact, contrary to their religiously segregated counterparts, the overarching goal of integrated schools is to foster an understanding of both the dominant traditions and to overcome negative stereotypes (see NICIE 2004a, 2004b). Attended in roughly equal numbers by Protestant and Catholic children, integrated schools are defined by the government as schools that have a 30 percent minimum enrolment from whichever side of the community forms a minority within that school. By educating children from both religious communities together and encouraging them to understand their historical and religious differences, both parents and educators hope that children educated within a religiously integrated setting will feel less threatened by the cultures and traditions of the other community, and be more likely to respect them, as well as form enduring cross-community relations. In the most contentious area, religious education, integrated schools provide interdenominational religious education required by the parents. In the other area of contention, the teaching of history, the integrated curriculum emphasizes local history in order to try and create a common heritage.

Importantly, no single model of integration unites Northern Ireland's integrated schools and they vary considerably with regard to how actively they promote integration (see Montgomery et al. 2003). Furthermore, not all staff in integrated schools have been equally proactive in achieving an integrationist ethos. In a recent study, Caitlin Donnelly (2004a, 2004b) found considerable disparity among teachers with regard to how an ethos of tolerance and respect could be created and maintained in the school. Donnelly and Joanne Hughes (2006) supported these findings and found that not only was there considerable disparity among parents, teachers, and principals as to what constituted an integrated ethos but discussions with pupils concerning politically contentious issues were deliberatively avoided. However, more so than any other factor, the key difference between integrated and segregated schools is their commitment to constitutional and structural safeguards to encourage joint ownership by the two traditions (Smith 2001). ${ }^{7}$

One explanation for these patterns is the relative newness of integrated schooling in Northern Ireland. It was not until 1981 and against vitriolic objections from church leaders in both communities that the first integrated school, Lagan College, was established by parents (see $\mathrm{O}^{\prime}$ Connor 2002 for a detailed historical account of this issue). So great was opposition to its establishment that it was originally funded from private sources, finally achieving government funding in 1984. Since then, between two and three new integrated schools a year have opened, all established either by grassroots initiative or through a parental ballot to give an existing school integrated status. By 2005 there were 58 schools at both the primary and post-primary level with a total enrolment of 16,691 pupils, accounting for 5.3 percent of the student population (see NICIE 2005:34). Of these 58 schools, the vast majority-39 schoolsare primary schools as compared to just 19 secondary schools. There are no formally integrated grammar schools. As a consequence of parental initiatives and the subsequent achievement in government funding, the integrated education sector has flourished since $1989 .{ }^{8}$

While the growth of integrated schools is remarkable, it has also generated tension and conflict (see Dunn and Morgan 1999), particularly since the mid-1990s, when government attempts to restrict educational expenditure discouraged further integration. Although the transformation of existing schools to integrated status was legally conceded as far back as the late 1970s (Education NI Act 1977), to date only a dozen schools have embarked on this

7. For example, all integrated schools have adopted the principle that both students and staff should be drawn from both cultural traditions and it is not unusual for parents from both religious communities to constitute roughly half of the governing body in integrated schools.

8. In 2004-2005, 3.9 percent of primary schoolchildren attended integrated schools, compared to 2.4 percent in 1998-1999; similarly, 11.4 percent of children in secondary schools attended integrated schools in 2004-2005, compared to 5.7 percent in 1998-1999 (see the NICIE website at www.nicie.org/ for additional statistical information). 
route, all of which have been preexisting (Protestant) state controlled schools (see Smith 2001:571). And, while some have welcomed their establishment, supporters of integration have either rejected this approach as unworkable or have expressed concerns about many aspects of the process. These concerns have covered issues such as the proportion of crosscommunity enrolment necessary, or the achievement of a balanced staff (see Morgan and Fraser 1999). Despite their objections, however, government policy coupled with falling student numbers suggests that this trend towards the transformation of existing schools to an integrated status will accelerate (see $A$ Shared Future [OFMDFM 2005]).

In summary, the key characteristic of education in Northern Ireland is the existence of two parallel-Protestant-controlled and Catholic-maintained-religiously based school systems, catering for Protestant and Catholic students separately. In recent years, this monolithic system has shown some signs of erosion. Currently, there is a small, but growing, integrated educational sector, accounting for just over 5 percent of the school population and attracting students not only from both religious traditions but from all socioeconomic backgrounds (see Gallagher, Smith, and Montgomery 2003). ${ }^{9}$ The introduction and development of this third element in the educational system-integrated schools-was based on the assumption that contact between divided groups within an educational setting can reduce sectarian attitudes and lead to better intergroup relations. Yet, as will be argued in the next section, empirical research in Northern Ireland remains both inconclusive and divided in terms of the impact of integrated education in reducing intergroup conflict and division within this society.

\section{Does Integrated Education Work?}

Previous empirical research on the relationship between integrated schools and relations between Protestants and Catholics in Northern Ireland is both limited and inconclusive (see McGlynn et al. 2004 for a review). Although several studies stress the positive benefits of integrated schooling, particularly in promoting cross-community friendships, others are more ambiguous, suggesting that it has little or no impact in promoting shared cultural outlooks. Some commentators even suggest that integrated education may actually reinforce divisive ethnic and political views.

The first major investigation of this issue by Colin Irwin (1991) found an increase in the number and duration of intercommunity friendships among pupils enrolled in an integrated school. Based on an evaluation of the friendship choices of Protestant and Catholic pupils, he found that after just five years of secondary education in an integrated school not only did pupils who had attended a segregated primary school have more friends from the "other" community than their own but, contrary to earlier research on short-term cross-community contact projects (see Trew 1986), these friendships continued into adulthood. Later research

9. Using the proportion of pupils in a school who were entitled to free school meals as an indictor of socioeconomic background, not only did Gallagher and colleagues (2003) find notably higher levels of social disadvantage in integrated schools as compared with grammar schools but there was little difference in the level of social disadvantage between integrated schools and their Protestant counterparts in both the primary and secondary sector. For example, whereas between 21 to 25 percent of students in integrated secondary schools were entitled to free school meals in 2001-2002, the equivalent figure among Protestant schools was almost identical at 24 percent. Overall, however, the highest level of social disadvantage was found in Catholic schools and this was true across all three-primary, secondary, and grammar-sectors. As Gallagher and colleagues (2003), in summarising their findings in relation to the popularist belief that children in integrated schools are exclusively drawn from middle class backgrounds, conclude: "The evidence suggests that the claim that integrated schools merely represent middle class alternatives to grammar schools is not supported by the evidence" (p. 17). Later research by McGlynn (2003) lends further support to this finding. In a follow-up study of 159 former pupils from two long-established integrated schools in Northern Ireland, not only did this study find that students had been drawn in significant numbers from both religious traditions but they also came from a wide variety of socioeconomic backgrounds. As McGlynn (2003), in rejecting the claim that integrated schools are schools for children of liberal and nonconformist middle class intellectuals, briefly concludes: "Whilst some of the 'founder' parents of School A might fit this stereotype, subsequent parents from both schools represent a wide social mix" (p. 20). 
has confirmed these findings. Maurice Stringer and associates (2000) compared 1,732 pupils from integrated and nonintegrated schools and found that pupils in integrated schools reported higher levels of social contact with members of the "other" community than children in segregated schools, and took a liberal position on mixed marriage and integrated education. There is also evidence to suggest that the integrationist attitudes formed during this period persist long after the school experience, even extending to the choice of a cohabitating or marital partner (McGlynn 2003; see also McGlynn et al. 2004). ${ }^{10}$

Although research suggests the positive influence of integrated schooling on community attitudes, the evidence in relation to its impact on religious and political identities is less conclusive. Although Carol McClenahan and colleagues (1996) found that cross-community friendships were increased by intergroup contact, they failed to detect any change in national or sociopolitical identity as a result of coeducation. Later research by Claire McGlynn (2003) on the adult population lends further support to these findings. Although the study found that the overwhelming majority (93 percent) of past pupils felt that integrated education had a significant positive impact on their lives, religious identity was unaffected and there was also little impact on political identity. In fact, in a small minority of cases, self-perceptions of religious and ethnic identity had been strengthened, rather than diminished, as a result of integrated education.

Research on the effects of desegregation on both the student and adult population in the United States confirms these findings (see Holme, Wells, and Revilla 2005; Schofield 1995; Wells and Crain 1994; Wells et al. 2005). Although a review of earlier research on the school population suggested that the impact of desegregated education on intergroup relations was both "inconclusive and inconsistent" (see Schofield 1995:611), later survey-based research has underscored the significance of desegregation in shaping the racial attitudes and experiences of students. Pointing to the positive effects of desegregation on racial attitudes, these later studies show that attending a racially integrated school significantly improves intergroup relations and increases students' ability to operate effectively in interracial settings. Minority students who had attended desegregated schools were also more likely to attend and succeed in college and to work in interracial settings (see The Civil Rights Project 2002; Eaton 2001; Wells and Crain 1994). The only comprehensive study of the long-term impact of school desegregation on the adult population reached similar conclusions (see Holme et al. 2005; Wells et al. 2005).

An important caveat to these U.S. studies on the long-term impact of school desegregation is that they are based on "hindsight" lessons, which participants only became aware of as adults. In fact, it was not until after they had left school and attended college or entered the workplace did these graduates realize what they had learned and the benefits of their experiences vis-à-vis their peers who had not attended diverse schools. Paradoxically, the vast majority of these graduates and their children had currently little or no contact with individuals of another racial group and were highly segregated in terms of housing, employment, social interaction, and religious observance. As Jennifer Jellison Holme, Amy Stuart Wells and Anita Tijerina Revilla (2005), in assessing the long-term impact of desegregated education on the U.S. population, conclude:

\footnotetext{
Although our data show that these graduates had not changed the world-in fact most have (often unwittingly) done their part as adults to perpetuate our segregated society-our findings do suggest that the experience of attending racially diverse schools may break down the cycle of segregation by giving them increased comfort in racially mixed settings, and decreased fear of racially mixed environments (p. 23).
}

10. McGlynn (2003) found strong integrationist views among her adult sample and in many cases these views also extended to the choice of partners, with more than half of the past pupils having a partner from a different religious and cultural background, compared to about 10 percent of the adult population (NILT 2003). A key factor contributing to this outcome was the school environment and not parental influence (McGlynn 2003:20-21). 
In summary, then, while there is a growing body of national and cross-national evidence to suggest that integrated schooling or coeducation has a significant and positive influence on the lives of those who experience it, most notably in terms of reducing prejudicial attitudes as well as promoting a sense of security in religious, racial, or ethnically diverse environments, previous research as to its impact on sociopolitical attitudes remains both rare and inconclusive. This is particularly the case in the United States where the impact of coeducation on identity patterns has not been previously assessed. Furthermore, at least as far as ethnic or religious identity in Northern Ireland is concerned, there is evidence to suggest that integrated education, or regular contact between the two main religious communities in a formal educational setting, may, in fact, have the opposite effect in reinforcing such allegiances. It is to a theoretical discussion of this issue-the impact of intergroup contact in alleviating conflict and division-to which we now turn.

\section{The Theoretical Framework}

\section{The Contact Hypothesis}

One of the most frequently applied approaches to conflict resolution is the contact hypothesis, and in Northern Ireland it has been widely endorsed by both the government and the academic community (see Gallagher 2003; Hughes 2003; Niens, Cairns, and Hewstone 2003). The idea that integrated contexts provide the best means of fostering reconciliation was first advanced in the 1940s by Williams (1947) and elaborated on by Allport (1954). In its simplest form, the contact hypothesis proposes that intergroup conflict can be reduced by bringing together individuals from opposing groups. One of the underlying assumptions is that conflict arises from lack of information about the other group and from lack of opportunities to obtain such information. Thus, according to the contact hypothesis, one of the most productive ways to reduce intergroup conflict and division is to encourage and promote contact between members of different racial and/or ethnic groups, resulting in more tolerant and positive attitudes. For this to happen, Allport (1954) suggested that four core conditions need to be met: (1) equal status between the groups in the situation; (2) common goals; (3) no competition between groups; and (4) the contact situation should be legitimized through institutional support.

Since it was first proposed by Allport (1954) over fifty years ago, the intergroup contact hypothesis has been extensively tested. Most of the research has compared the attitudes of participants before and after intergroup contact, in an attempt to determine if contact is indeed effective in improving intergroup relations (see Pettigrew 1998). Findings have, in general, indicated that even in situations lacking Allport's key conditions, intergroup contact usually has positive effects. ${ }^{11}$ For example, Thomas Pettigrew and Linda Tropp (2000), in an extensive review of the literature, not only found that intergroup contact significantly reduced ethnic and racial conflict but concluded that optimal intergroup contact, such as structured programs that ensure that all or most of Allport's four core conditions are met, was a key aspect of any successful effort to reduce prejudice. In fact, according to Pettigrew (1998), provided a number of interrelated and sequential process are achieved under these optimal conditions, not only may intergroup contact mediate positive attitudinal change and reduce intergroup conflict but it can also result in the development of an overarching identity

11. This is not to suggest, however, that contact theory has been immune to criticism. For example, a key problem as Allport himself acknowledged, is that the causal direction between contact and the reduced intergroup conflict may be equivocal. More recent research suggests that the issue of causal direction may not be as problematic as originally anticipated. Indeed, longitudinal, experimental, and meta-analytic studies all provide converging evidence that intergroup contact can contribute to reducing prejudice (see Pettigrew and Tropp 2006; Tropp and Pettigrew 2005). 
in which participants perceive themselves as sharing a common or singular identity with outgroup members. ${ }^{12}$

More recent research suggests that, even when all of Allport's optimal conditions have been met, problems can still arise that can militate against positive attitudinal change and heighten intergroup conflict. For example, as Tropp and Pettigrew's (2005) investigation of intergroup contact and prejudice among minority and majority status groups suggests, even in situations under optimal conditions, majorities and minorities can perceive the same objective situation in contrasting and conflicting ways. Thus, what may appear as equal group status in the contact situation to majority members may appear to minority members as potentially threatening and unequal. This mitigation against attitudinal change and the reinforcement of conflict seems to occur particularly in interracial or multiethnic contexts where groups are more marginally imbalanced in size. This is in contrast to situations where there is a numerical majority dominating the smaller group. Furthermore, there is some evidence to suggest that, even in situations under optimal conditions, contact appears to have a stronger impact on the attitudes of high-status majority groups rather than on low-status minority groups, and this is particularly the case when contact between different racial or ethnic groups are considered. For example, Tropp and Pettigrew (2005), using data from a larger meta-analysis of some 500 studies involving contact among groups of differing status positions within society, not only found that the contact-prejudice effects varied significantly in terms of the societal status of the groups involved but this was also the case even when Allport's four conditions were met. More specifically, whereas intergroup contact under these circumstances was a significant factor in reducing prejudice among majority status group members, the relationship between intergroup contact and a reduction in prejudice was much weaker among members of low status groups (see Tropp and Pettigrew 2005 for a comprehensive discussion of this issue).

An empirical examination of the impact of the educational system on political attitudes in Northern Ireland may be considered an appropriate case study for investigating the impact of contact theory on reducing intergroup conflict. Our arguments in support of this proposition are threefold. First, previous research in the United States and elsewhere attests to the importance of desegregated schools in alleviating racial and ethnic conflict even under situations where all of Allport's conditions-such as involuntary attendance or a competitive atmosphere-have not been met (see Pettigrew 1998:68). In fact, despite a perceived lack in optimal conditions, more recent research suggests the interracial contact at school is a more effective mechanism in disconfirming racial and ethnic stereotypes than contact in other interactive settings such as one's community of residence or place of work. For example, Dixon and Rosenbaum (2004), in a recent empirical investigation on the effects of whites' contacts with blacks and Hispanics in different interactive settings, found that prior contact in a school environment was the primary factor in reducing racial prejudice. In other words, it was contact in the school and not in other interactive settings such as one's current community of residence, workplace, or even family contact, which emerged as the key and consistent factor in ameliorating anti-black and anti-Hispanic stereotypes among whites in this instance.

Second, unlike many of their desegregated U.S. counterparts, at least in principal, integrated schools in Northern Ireland explicitly aim to fulfil all of Allport's optimal conditions in reducing intergroup conflict. As noted earlier, not only do integrated schools seek to actively and explicitly promote cooperation and shared cultural understanding among students across denominational lines but through their recruitment practices and management structure they also aim to promote equal-status roles for students (and parents) from both religious

12. These four interrelated and sequential processes include learning about the out-group, changing behavior, generating affective ties, and in-group appraisal. In other words, according to Pettigrew (1998), to achieve a maximum reduction in prejudice, first people should get to know each other as friends, that they should then understand that they come from two opposing groups, and finally that an attempt should be made to forge a common identity. 
traditions. One key difference between integrated and segregated schools in Northern Ireland is their commitment to constitutional and structural safeguards to encourage joint ownership by the two traditions. By encouraging children to understand their historical and religious differences, integrated schools not only attempt to foster a social climate that supports interreligious cooperation and association, as modelled by authority figures such as teachers and principals, but also to provide opportunities for Protestant and Catholic children to work and learn cooperatively together to achieve common goals, namely the creation of a common heritage based on local history. Thus, in principle at least, if not always in practice, integrated schools may be considered to meet most of Allport's optimal conditions.

Third, Northern Ireland remains a deeply segregated and polarized society. Not only are the two main religious communities-Protestant and Catholic-segregated in terms of their schooling patterns, but this division extends into all areas of social life. So great is the level of polarization and the deliberate avoidance of any interaction with the other religious community, that for many people they will have little or no contact with a member of the opposing religious tradition prior to attending university or entering the workforce. It is for this reason-the absence of any contact between the two religious communities except in a school setting - that the use of contact theory as our guiding theoretical framework may be considered particularly appropriate in this instance.

This is not to deny the possibility of other mechanisms, most notably the school environment and its associated curriculum, in influencing political outlooks in this instance. The educational system in Northern Ireland still remains sharply divided along religious lines and this is particularly the case when the cultural ethos within the school, or the school environment, is considered. Despite recent changes, most notably the introduction of a common curriculum in 1990, children within these religiously divided schools are not only taught by teachers drawn exclusively from their own tradition but they also continue to celebrate different events and holidays and, more importantly, follow two different curriculum-a pro-British one in both informally integrated and state schools, both of which are essentially Protestant schools, as compared to a more Irish-centered one in Catholic schools. Critics of the existing system believe that the educational experience of schoolchildren in Northern Ireland is so partisan in nature that to address the problem of prejudice and sectarianism not only would both school systems-informally integrated and segregated-have to develop a new ethos and character but they could only do so by abandoning their existing one.

Similar concerns have also been raised about the school ethos and curriculum content in formally integrated schools. And, while formally integrated schools have sought to address explicitly this issue via the development of new curriculums and pedagogies, there is some evidence to suggest that this aspect of the school is being seriously undermined, in part due to the turnover of staff and the limited specific training for teachers wishing to work in integrated settings but particularly because of their overconcentration on contact work (see Gallagher 2004 for a discussion of this issue). Some scholars go so far as to suggest that this overemphasis on contact in integrated schools, as opposed to curricular work, which has tended to be given a relatively low priority, has seriously hampered efforts to provide a genuinely integrated environment. Added to which, the "social grammar" that exists in Northern Ireland, whereby people, to avoid causing discomfort and offence, do not talk about issues of politics in religiously mixed company is also evident in integrated schools. As Tony Gallagher (2004) notes, this unwritten social rule means that people can engage in cross-community contact while remaining largely ignorant of the views of members of the "other" community on fundamental social divisions within society. It is these two alternative factors-the particular school ethos as well as the specific content of the curriculum-and not the nature or level of intergroup contact, which may account for differences in political outlooks in this instance. Unfortunately, however, because of a lack of suitable data we are unable to test empirically this competing explanation here. 


\section{Hypotheses}

Using the contact hypothesis as our theoretical framework, this study examines the impact of integrated education on adult attitudes in Northern Ireland. More specifically, we investigate the degree to which individuals from the two main religious communities who attended either a formally or informally integrated school differ in their political outlooks from those who attended a religiously segregated one. Northern Ireland remains a deeply divided society and this is particularly the case when the question of national identity and constitutional preferences are concerned. In fact, so pervasive and deeply-rooted are these divisions in identity and territorial allegiances between the two religious communities that not only have children as young as six years of age already acquired a negative evaluation of members of the opposite religion but by the age of 10 and 11 they are able to clearly distinguish in-group and out-group members (see Hayes and McAllister 1999b for a review of this literature).

The relationship between intergroup contact within a religiously mixed educational setting and a less sectarian or traditionally entrenched and divisive outlook in political attitudes is our central hypothesis. Individuals attending a formally or informally integrated school will, therefore, be less sectarian in their outlooks compared to an individual who has attended a segregated school (Hypothesis 1), but the more recent theoretical literature also prompts us to investigate this relationship in greater detail. We argued earlier that the relationship between contact and a reduction in intergroup prejudice is strongest when Allports's four conditions are met. We thus hypothesize that less sectarian attitudes in relation to national identity and constitutional preferences will be strongest among adults who attended a formally integrated school as compared to those who attended an informally integrated one (Hypothesis 2). Drawing on Pettigrew's (1998) suggestion of the possibility of a singular identity, we also hypothesize that individuals who have attended these formally or informally integrated schools will be the most likely to have developed an overarching in-group identity or, in this case, one that is distinctive from the two competing and traditionally established identity preferences and constitutional allegiances (Hypothesis 3). ${ }^{13}$

The final hypotheses take into account Tropp and Pettigrew's (2005) work in relation to majority-minority relations. We hypothesize that, even in situations where Allport's four conditions are more likely to be met, such as among individuals who had attended a formally integrated school, a reduction in divisive political outlooks will be more likely among high-status individuals than low-status group members, or in this case more among Protestants than Catholics (Hypothesis 4). However, in situations where Allports's four conditions are absent, such as individuals who have been in a clear minority position at school (those who cross the religious divide and attended a segregated school different to their own), we anticipate that it will be members of minority groups, or Catholics in this instance, who will be not only more likely to move away from their traditional political allegiances but also to accommodate and possibly adopt the attitudes of their majority (Protestant) colleagues (Hypothesis 5).

One caveat surrounding this investigation is the difficulty in assigning causality. Since our analysis is based on aggregated cross-sectional surveys, we do not know the outlooks of the respondents or their parents before they entered an integrated school. For example, it could be argued that more liberally-minded parents are more likely to send their children to integrated schools, and that any effects we attribute to schooling may in fact be due to selectivity among parents. Research in both the United States and Northern Ireland casts doubt upon this interpretation (see Hewstone 2003; McGlynn 2003; Pettigrew 1997; Tropp and Pettigrew 2005). Our arguments in support of this position are threefold.

13. This is not to deny, however, our lack of knowledge as to the specific mechanisms and the sequencing of events by which these individuals were exposed to an integrationalist ethos within their various integrated schools. 
First, previous experimental research in the United States demonstrates that contact can and does affect attitudes (Cook 1978). Second, we know from analyses that have estimated the causal effects from cross-sectional data that the path from contact to attitudes tends to be stronger than the reciprocal path (Pettigrew 1997). There is now a growing and converging body of studies-longitudinal, experimental, and meta-analytic-to suggest that intergroup contact can lead to a reduction in prejudice (see Tropp and Pettigrew 2005:951). Third, at least as far as Northern Ireland is concerned, there is empirical evidence to suggest that contact between the two religious communities in an integrated educational setting also affects attitudes. Previous research demonstrates that not only are pupils in integrated schools in Northern Ireland drawn from a variety of social backgrounds but they attract children who had little or no contact with the "other side" prior to integrated schooling, suggesting that it is the school environment and not parental influence which determines their attitudes (see McGlynn 2003:1 1-28). ${ }^{14}$

\section{Methods}

\section{Data}

The data used in the analysis are based on a pooled sample of the 1998 to 2003 Northern Ireland Life and Times Surveys (ARK 1998-2003) and the 1998 and 2003 Northern Ireland Election Surveys (ARK 1998, 2003). The 1998 through 2003 Northern Ireland Life and Times Surveys are nationally representative surveys of the Northern Ireland population conducted in the autumn of each year, based on a random sample of the adult population aged 18 years or over. The 1998 Referendum and Election Survey was a nationally representative postelection survey of all adults aged 18 years or older conducted immediately after the Northern Ireland assembly elections in June 1998, while the 2003 Northern Ireland Election Study was a nationally representative post-election survey of all adults aged 18 years or older conducted immediately after the Northern Ireland assembly elections in November 2003. All of the surveys are based on personal interviews. Given our research question of interest, only individuals who explicitly identified themselves as members of the two main religious communitiesProtestant and Catholic - are included in the investigation. This accounted for 11,522 individuals, or 88.5 percent of the total pooled sample and 99.7 percent of those who explicitly claimed a religious affiliation.

\section{Measurement}

Dependent Variables. The two dependent variables are identity and constitutional preferences, which reflect the main communal divisions in Northern Ireland. Two dimensions of identity are investigated in the analysis. The first is national identity, which was operationalized by the question: "Which of these describes best the way you think of yourself?," with the response options British, Irish, Ulster, Northern Irish, or other. The second aspect of identity is political identity, which was operationalized by the question: "Generally speaking, do you think of yourself as a unionist, a nationalist, or neither?" Responses to these two questions have also been combined to create a "congruency in identity" variable, measured by the degree to which Protestants perceive themselves as both British and Unionist versus those who do not and the number of Catholic respondents who see themselves as both Irish and

14. This is an issue, however, that can only be comprehensively resolved by extensive, long-term panel studies. 
Nationalist versus those who do not. ${ }^{15}$ Constitutional preference was operationalized by the question: "Do you think that the long-term policy for Northern Ireland should be for it to remain part of the United Kingdom or to reunify with Ireland?," with the response categories to remain part of the United Kingdom or to reunify with the rest of Ireland. ${ }^{16}$

Independent Variables. Our main independent variable is type of education, measured by the question: "Did you ever attend a mixed school or integrated school in Northern Ireland, that is, a school with fairly large numbers of both Catholic and Protestant children?" The response categories were yes or no. Individuals who said "yes" were asked: "Was this a formally integrated school or was it a school that was just fairly mixed?" Using these two questions, three groups are distinguished in the analysis: individuals who reported attending an integrated school that was a formally integrated school; individuals who reported attending an integrated school that was just fairly mixed; and individuals who said that they had not attended either a mixed school or integrated school in Northern Ireland, or respondents who answered no to question one.

An important limitation is that we do not know on what numerical basis the respondents evaluated the religious composition of these schools. While it could be argued that this measure has limited utility, it does have value in identifying the proportion of the population who had some experience of meeting children of the opposite religion at school, albeit not in a formally integrated context. Also, as we noted earlier, because Catholic children are more likely than Protestant children to cross the religious divide and attend a segregated school different to their own religion, we can correctly assume that the vast majority of these informally integrated, or just fairly mixed, schools are, in fact, Protestant schools with a significant Catholic minority.

Control Variables. We also include several other measures as controls in the multivariate models, given previous research as to their significant association with identity patterns and constitutional preferences in Northern Ireland (see Fahey et al. 2006 for a recent overview of this literature). These variables are gender, church attendance, age, education, ${ }^{17}$ occupation, and employment status and are described in Table $1 .{ }^{18}$ Protestants are generally older (50.1 years) than Catholics (45.8 years), reflecting the higher levels of fertility among Catholics. They are also more likely than Catholics to be employed and to work in nonmanual occupations and are significantly less likely to lack any educational qualifications, a not unexpected finding given their traditionally established economically privileged position within Northern Ireland society. Catholics, by contrast, are more likely to attend church on a regular basis than Protestants and, as expected, are notably less likely than their Protestant counterparts to come from Protestant homes.

\section{Analysis}

In order to assess the impact of type of school on political preferences, a series of bivariate and multivariate analyses were undertaken. Our analytic strategy was to compare the opinions not only of Protestants and Catholics in relation to this issue but also to distinguish between those who had attended either an informally or formally integrated school. The overall strength of the relationships in the bivariate analyses was measured using Chi-squared tests

15. National identity and constitutional preferences are usually, but not always congruent, with Protestants generally seeing themselves as British and Unionist, and Catholics as Nationalist and Irish (see Hayes and McAllister 1999a). The two measures are highly correlated, and provide a convenient summary measure. Analyses using the two items separately reach substantively the same conclusions.

16. In addition, if respondents volunteered either an "independent state" or some other answer as their preferred constitutional outcome this option was also recorded.

17. Tertiary education is generally a degree or graduate diploma, secondary qualifications are those gained at age 15 or 16 years. The remainder are those without any formal educational qualifications.

18. These were the most extensive socioeconomic control variables available in the data set. 
Table 1 • Description of Independent Variables, Northern Ireland 1998-2003 Pooled Sample

\begin{tabular}{|c|c|c|c|c|c|c|c|}
\hline \multirow[b]{2}{*}{ Variable } & \multirow[b]{2}{*}{ Coding of Variables } & \multicolumn{2}{|c|}{$\begin{array}{l}\text { Protestant } \\
(\mathrm{n}=6,878)\end{array}$} & \multicolumn{2}{|c|}{$\begin{array}{c}\text { Catholic } \\
(\mathrm{n}=4,730)\end{array}$} & \multicolumn{2}{|c|}{$\begin{array}{c}\text { Total } \\
(\mathrm{n}=11,608)\end{array}$} \\
\hline & & Mean & Std Dev & Mean & Std Dev & Mean & Std Dev \\
\hline Gender (male) & $1=$ male, $0=$ female & .42 & - & .41 & 一 & .42 & - \\
\hline $\begin{array}{l}\text { Church attendance } \\
\text { (attends) }\end{array}$ & $\begin{array}{l}7 \text { point scale ranging } \\
\text { from } 0 \text { to } 1\end{array}$ & $.56^{*}$ & .39 & .80 & .33 & .65 & .38 \\
\hline Age (years) & From 18 to 96 years & $50.08^{*}$ & 18.27 & 45.80 & 17.64 & 48.37 & 18.15 \\
\hline Education: & All coded 1 or 0 & & & & & & \\
\hline Tertiary & & .16 & - & .15 & - & .16 & - \\
\hline Secondary & & .39 & - & .36 & - & .38 & - \\
\hline No qualification & & $.45^{*}$ & - & .48 & - & .46 & - \\
\hline Occupation & $\begin{array}{l}1=\text { nonmanual } \\
0=\text { manual }\end{array}$ & $.53 *$ & - & .45 & - & .50 & - \\
\hline Employment & $\begin{array}{l}1=\text { in labor force } \\
0=\text { not in labor force }\end{array}$ & $.45^{*}$ & - & .43 & - & .44 & - \\
\hline Parental religion & $\begin{array}{l}1=\text { Protestant } \\
0=\text { Catholic }\end{array}$ & $.98^{*}$ & - & .01 & - & .60 & - \\
\hline
\end{tabular}

Sources: Northern Ireland Referendum and Election Survey, 1998 (ARK 1998); Northern Ireland Election Study, 2003 (ARK 2003)

*significantly different from Catholics at the .05 level or above (two-tailed test)

and, in all cases, the specific location of the various differences in the relationship was estimated by a series of $t$-tests. ${ }^{19}$

The analysis proceeds in a number of stages. First, by way of introduction, we present the proportion of Protestants and Catholics within the adult population by type of school attended. Then, via two logistic regression models-one for formally integrated versus segregated schools and one for informally integrated versus segregated schools-we estimate systematically the degree to which there are any differences between Protestants and Catholics in relation to this issue. ${ }^{20}$ We then turn to the impact of school integration on political attitudes. Starting first with national identity, we begin the investigation by presenting the proportion of Protestants and Catholics in terms of their various identity preferences as well as congruency in identity preferences by type of school attended. To estimate the degree to which type of school attended is an independent and significant predictor of congruency in identity patterns within both religious communities, we then estimate two separate multiple logistic regression models, one for Protestants and one for Catholics, which includes type of school attended, as well as a number of sociodemographic control variables such as gender, church attendance, age, and socioeconomic background. The analysis in terms of constitutional preferences proceeds in an identical manner.

The purpose of the various analyses is to investigate whether or not the long-term effects of integrated schooling on identity and territorial allegiances lend support to the contact thesis and its various qualifying conditions. More specifically, irrespective of whether national identity or constitutional preferences are considered, we wish to investigate whether or not

19. In terms of the $t$-test calculations, only statistically significant differences are indicated in the various tables and are, within both religious communities, denoted by two subscripts, a and b; whereas subscript a denotes differences between those who attended a formally integrated school and those who did not, subscript b distinguishes between those who attended an informally integrated school versus those who attended a religiously segregated one.

20. In addition to parental religious denomination, a number of control variables such as age and gender are also included in the analysis. Unfortunately, however, because data on parental socioeconomic background were not available in the data set, we could not control for this factor in the analysis. However, as noted earlier (see footnote 9), previous research suggests that there are no differences between children in terms of type of school attended-integrated versus segregated-in relation to this issue. 
individuals who had attended either a formally or informally integrated school are less sectarian in their views than those who did not (Hypothesis 1); whether this reduction in sectarian attitudes is particularly the case among adults who attended a formally integrated school (Hypothesis 2); whether this reduction in sectarian attitudes will result in an overarching ingroup identity among the various individuals involved (Hypothesis 3); whether this development of an overarching identity among those educated in a formally integrated setting is more common among Protestants than Catholics (Hypothesis 4); and, finally, whether, individuals who were in a clear minority position at schools (Catholics in informally integrated schools) are more likely to abandon their traditionally established sectarian positions in favor of the dominant, or Protestant, view (Hypothesis 5).

\section{Results}

The breakdown in type of school attended in Table 2 presents the proportion of Northern Ireland adults who had experienced either an integrated or a segregated education by religious background. The data in column 3 shows that, between 1989 and 2003, 11.6 percent of Northern Ireland adults claimed to have attended a religiously mixed school. When the proportion of adults who had attended a "formally integrated" versus a "fairly mixed" school is disaggregated this leads to a much lower estimate of 1.4 percent of the total adult population attending an integrated school, very close to the government estimate of 1.7 percent. By contrast, 10.2 percent of those who report attending a mixed school said that it was not formally integrated, just one that was fairly mixed. The accuracy of these results is supported by the age distribution of the respondents experiencing formally integrated education: of those aged 18 to 24 years old when interviewed, 4.4 percent said that they had attended a formally integrated school, compared to just 0.5 percent of those aged 70 or over (results not shown here). There is a statistically significant difference between Protestants and Catholics in relation to this issue (Chi-square $=36.362, p<0.01$ ), which, as the results from the series of $t$-test calculations attest, is manifested across all three educational sectors. For example, a significantly lower proportion of Protestants (87 percent) as compared to Catholics (90 percent) report attending a segregated school, and a notable and comparatively higher proportion-12 percent as compared to 8 percent-say that it was one that was just fairly mixed.

Table 3 further explores these differences using two logistic regression models, one for formally integrated versus segregated schools and one for informally integrated versus segregated schools. Looking at the effects of religious denomination, while no statistically significant differences emerged between the two religious communities in relation to formally

Table 2 - Religious Denomination and School Integration in the Adult Population in Northern Ireland

\begin{tabular}{lccc}
\hline & Protestant & Catholic & Total \\
\cline { 2 - 4 } & \multicolumn{3}{c}{ Percentages } \\
\hline Formally integrated & $1.2^{*}$ & 1.7 & 1.4 \\
Informally integrated & $11.5^{*}$ & 8.2 & 10.2 \\
Segregated & $87.3^{*}$ & 90.1 & 88.4 \\
Total & 100.0 & 100.0 & 100.0 \\
$(N)$ & $(6,810)$ & $(4,712)$ & $(11,522)$ \\
Chi-square $=36.362,2 \mathrm{df}, p<.01$ & & \\
\hline
\end{tabular}

Sources: Northern Ireland Referendum and Election Survey, 1998 (ARK 1998); Northern Ireland Election Study, 2003 (ARK 2003)

*significantly different from Catholics at the .05 level or above (two-tailed test) 
Table 3 - The Impact of Parental Religion on School Integration in the Adult Population in Northern Ireland

\begin{tabular}{lcccc}
\hline & \multicolumn{3}{c}{ Logistic Regression Coefficients } \\
\cline { 2 - 5 } & \multicolumn{2}{c}{ Formally Integrated } & Informally Integrated \\
\hline $\begin{array}{l}\text { Sociodemographic controls } \\
\text { Gender (male) }\end{array}$ & $-.47^{* *}$ & $(.17)$ & -.03 & $(.06)$ \\
Age & & & & \\
18 to $29^{a}$ & - & - & - & $(.10)$ \\
30 to 39 & $-.73^{* *}$ & $(.21)$ & $-.32^{* *}$ & $(.11)$ \\
40 to 49 & $-1.18^{* *}$ & $(.26)$ & $-.35^{* *}$ & $(.11)$ \\
50 to 59 & $-.91^{* *}$ & $(.25)$ & $-.34^{* *}$ & $(.11)$ \\
60 to 69 & $-1.59^{* *}$ & $(.33)$ & $-.25^{*}$ & $(.10)$ \\
$70+$ & $-1.93^{* *}$ & $(.36)$ & -.19 & $(.07)$ \\
Parental religion (Protestant) & -.20 & $(.16)$ & $.38^{* *}$ & \\
Constant & $-3.00^{* *}$ & & $-2.15^{* *}$ & $(11,249)$ \\
$(N)$ & $(10,253)$ & & \\
\hline
\end{tabular}

Sources: Northern Ireland Referendum and Election Survey, 1998 (ARK 1998); Northern Ireland Election Study, 2003 (ARK 2003)

Note: Logistic regression equations showing parameter estimates and (in parentheses) standard errors predicting the probability of formally or informally integrated schooling as against segregated schooling. ${ }^{a}$ omitted category of comparison ${ }^{*} p<.05 * * p<.01$ (two-tailed tests)

integrated versus segregated schools, Protestants were significantly more likely to have attended a nonsegregated school within a fairly mixed setting than their Catholic counterparts, even when a range of background characteristics were taken into account. This preponderance of adults from a Protestant background who attended informally integrated schools may simply be explained by the Protestant nature of these schools.

Turning to the long-term effects of integrated schooling on national and political identity, Table 4 presents the breakdown in type of school by identity for both Protestants and Catholics. Focusing initially on Protestants, an overall inspection of Table 4 suggests some statistically significant differences among Protestants between type of school attended and attitudes towards both national (Chi-square $=20.424, p<0.01$ ) and political identity (Chi-square $=$ $16.995, p<0.01)$. In both cases, Protestants who had attended a formally integrated school stand out as being different in their attitudes than those who had not. For example, whereas at least seven out of every ten Protestants who had attended either a segregated or informally integrated school chose the two dominant identities-British and unionist-the equivalent figure among those who had experienced a formally integrated education was significantly lower at just 63 percent (British) and 54 percent (unionist) respectively. Thus, and in partial support of Hypothesis 1, at least as far as the impact of integrated schooling on support for the two dominant identities is concerned, it is attendance at a formally integrated school, and not an informally integrated one, that emerges as the key attribute in distinguishing attitudes between those who were educated in an integrated versus a segregated setting in this instance.

A similar, albeit converse, pattern emerges when nontraditional and less sectarian practices such as the adoption of a Northern Irish identity or the absence of a political label are considered. Here, and in confirmation of Hypotheses 2 and 3, it is Protestants who have experienced a formally integrated education who stand out as the most supportive in their views. For example, whereas over two-fifths of Protestants who had attended a formally integrated 
Table 4 - School Integration and Identity by Religious Denomination in the Adult Population in Northern Ireland

\begin{tabular}{|c|c|c|c|c|c|c|c|c|}
\hline & \multicolumn{4}{|c|}{ Protestant } & \multicolumn{4}{|c|}{ Catholic } \\
\hline & $\begin{array}{l}\text { Formally } \\
\text { Integrated }\end{array}$ & $\begin{array}{l}\text { Informally } \\
\text { Integrated }\end{array}$ & Segregated & All & $\begin{array}{l}\text { Formally } \\
\text { Integrated }\end{array}$ & $\begin{array}{l}\text { Informally } \\
\text { Integrated }\end{array}$ & Segregated & All \\
\hline & \multicolumn{8}{|c|}{ Percentages } \\
\hline \multicolumn{9}{|l|}{ National identity } \\
\hline British & 63.4 & $71.5^{a}$ & $72.2^{a}$ & 72.0 & 11.1 & 12.1 & 9.3 & 9.5 \\
\hline Irish & 3.7 & 2.8 & 2.5 & 2.6 & 59.3 & 56.3 & $64.8^{b}$ & 64.0 \\
\hline Ulster & 3.7 & 5.6 & $8.2^{a}$ & 7.8 & 1.2 & .5 & .6 & .6 \\
\hline Northern Irish & 24.4 & 17.9 & $15.3^{a}$ & 15.7 & 27.2 & 29.5 & $24.0^{b}$ & 24.5 \\
\hline Other & 4.9 & 2.1 & 1.8 & 1.8 & 1.2 & 1.6 & 1.4 & 1.4 \\
\hline Total & 100.0 & 100.0 & 100.0 & 100.0 & 100.0 & 100.0 & 100.0 & 100.0 \\
\hline \multirow[t]{2}{*}{$(N)$} & $(82)$ & $(780)$ & $(5,903)$ & $(6,765)$ & $(81)$ & $(380)$ & $(4,186)$ & $(4,647)$ \\
\hline & \multicolumn{4}{|c|}{$($ Chi-square $=20.424,8 \mathrm{df}, p<.01)$} & \multicolumn{4}{|c|}{$($ Chi-square $=12.632,8 \mathrm{df}, p<.01)$} \\
\hline \multicolumn{9}{|l|}{ Political identity } \\
\hline Unionist & 54.3 & $71.2^{a}$ & $73.2^{a}$ & 72.7 & .0 & 1.6 & 1.0 & 1.0 \\
\hline Nationalist & 2.5 & .7 & .8 & .8 & 58.5 & 57.9 & $66.4^{b}$ & 65.6 \\
\hline Neither & 43.2 & $28.1^{a}$ & $26.0^{a}$ & 26.5 & 41.5 & 40.5 & $32.6^{b}$ & 33.4 \\
\hline Total & 100.0 & 100.0 & 100.0 & 100.0 & 100.0 & 100.0 & 100.0 & 100.0 \\
\hline \multirow[t]{2}{*}{$(N)$} & $(81)$ & $(768)$ & $(5,843)$ & $(6,692)$ & $(82)$ & $(375)$ & $(4,166)$ & $(4,623)$ \\
\hline & \multicolumn{4}{|c|}{$($ Chi-square $=16.995,4 \mathrm{df}, p<.01)$} & \multicolumn{4}{|c|}{$($ Chi-square $=14.715,4 \mathrm{df}, p<.01)$} \\
\hline
\end{tabular}

Sources: Northern Ireland Referendum and Election Survey, 1998 (ARK 1998); Northern Ireland Election Study, 2003 (ARK 2003)

Note: ${ }^{a}$ significantly different from the formally integrated at .05 level or above (two-tailed tests)

${ }^{b}$ significantly different from the informally integrated at the .05 level of above (two-tailed tests)

school chose to reject a unionist labor in favor of the intermediate and neutral "neither" position, the equivalent figure among those who had experienced either an informally integrated or segregated education was notably lower at just 28 percent and 26 percent respectively.

This is not to deny the marked unwillingness of Protestants to cross traditional allegiances and associate with the opposing identity, a result all the more persuasive given their lack of indecision in relation to this issue. ${ }^{21}$ Even among those educated in formally integrated schools, almost no Protestant was willing to identify himself or herself as Irish (less than four percent in both cases) or to adopt a nationalist identity (less than three percent). Thus, in further confirmation of Hypothesis 3, Protestants who had experienced a formally integrated education may be considered to occupy the middle ground of Northern Ireland politics in that they are willing to detach themselves from the dominant poles of identityBritish and unionist-but reticent to adopt the identity of the other side. Finally, as an inspection of the relationship between school type and identity patterns within the Catholic population indicates, and as predicted by Hypothesis 4, there is evidence to suggest that this significantly greater propensity among the formally integrated to abandon traditionally established views in favor of a more neutral position is an exclusively Protestant phenomenon.

21. In both instances, less than one percent of Protestants opted for the "don't know" category when asked to indicate their national and political identity. 
An inspection of Table 4 also suggests some statistically significant differences among Catholics between type of school attended and attitudes towards national (Chi-square = 12.623, $p<0.01$ ) and political identity (Chi-square $=14.715, p<0.01$ ), although the impact of the educational sector is not as clearly differentiated in this instance. Furthermore, and in partial confirmation of Hypothesis 1, the key and statistically distinguishing factor that emerges from this investigation is attendance at an informally integrated school versus a segregated one. For example, 56 percent of Catholics who had attended an informally integrated school claimed an Irish identity, but the equivalent proportion among those who had experienced a segregated education was higher at 65 percent. A similar, albeit converse, pattern emerges when nontraditional and less sectarian practices, such as the adoption of a Northern Irish label, are considered. For example, 30 percent of Catholics who had attended an informally integrated school claimed a Northern Irish identity compared to 24 percent of those who had experienced a segregated education.

There is a marked unwillingness among Catholics to cross traditional allegiances and associate with the opposing identity. Even among those educated in either an informal or formally integrated setting, almost no Catholic was willing to adopt a unionist label and, irrespective of school background, just one in ten was willing to identify himself or herself as British. Thus, at least as far as the Catholic population in concerned, the evidence in support of our various hypotheses is not as pervasive or clearcut. Only in relation to Hypotheses 1 and 3-the proposed differing and more moderate views in relation to identity patterns among those who had experienced an informally integrated education as compared to those who had attended a segregated school-is there some and, in the case of Hypothesis 1, only partial evidence in support of our various expectations at the bivariate level.

Integrated education is important in shaping identity. When the relationship between school integration and congruency in identity within the Protestant community is considered, it is again Protestants who had attended a formally integrated school who stand out as being the least traditionalist in their views (see Table 5). Protestants who had attended a formally integrated school were significantly less likely to identify themselves as both British and unionist than those who had not. For example, whereas just over a third of Protestants who had attended a formally integrated school claimed both a British and a unionist identity the equivalent percentages among those educated in either an informally integrated or segregated educational setting were notably higher at 57 percent and 58 percent respectively. Among Catholics, the key distinguishing factor was attendance at an informally integrated school versus a religiously segregated one. Catholics who had attended an informally integrated school were less likely to identify themselves as both Irish and nationalist than those who had experienced a segregated education. More specifically, whereas only around twofifths of all Catholics who had attended an informally integrated school claimed both an Irish and nationalist identity just over half of all Catholics who had experienced a segregated education did so.

Table 5 - School Integration and Congruency in Religious, National, and Political Identity in the Adult Population in Northern Ireland

\begin{tabular}{|c|c|c|c|c|}
\hline & Formally Integrated & Informally Integrated & Segregated & (Total) \\
\hline & \multicolumn{4}{|c|}{ Percentages } \\
\hline Protestant: British-Unionist & 35.5 & $56.5^{a}$ & $57.5^{a}$ & $(57.1)$ \\
\hline Catholic: Irish-Nationalist & 43.8 & 42.2 & $51.8^{b}$ & $(50.9)$ \\
\hline
\end{tabular}

Sources: Northern Ireland Referendum and Election Survey, 1998 (ARK 1998); Northern Ireland Election Study, 2003 (ARK 2003)

Note: ${ }^{a}$ significantly different from the formally integrated at .05 level or above (two-tailed tests)

${ }^{b}$ significantly different from the informally integrated at the 0.05 level of above (two-tailed tests) 
Table 6 - The Impact of School Integration on Congruency in Religious, National and Political Identity in the Adult Population in Northern Ireland

\begin{tabular}{|c|c|c|c|c|}
\hline & \multicolumn{4}{|c|}{ Logistic Regression Coefficients } \\
\hline & \multicolumn{2}{|c|}{$\begin{array}{c}\text { Protestants: } \\
\text { British-Unionist }\end{array}$} & \multicolumn{2}{|c|}{$\begin{array}{c}\text { Catholics: } \\
\text { Irish-Nationalist }\end{array}$} \\
\hline \multicolumn{5}{|l|}{ Sociodemographic controls } \\
\hline Gender (male) & $.19 * *$ & $(.06)$ & $.53 * *$ & $(.08)$ \\
\hline Church attendance (scale) & $.42^{* *}$ & $(.08)$ & $.47^{* *}$ & $(.11)$ \\
\hline Age (years) & $.01^{* *}$ & $(.00)$ & $-.01 * *$ & $(.00)$ \\
\hline \multicolumn{5}{|l|}{ Education: } \\
\hline Tertiary & $-.72^{* *}$ & $(.10)$ & $-.28^{*}$ & $(.12)$ \\
\hline Secondary & $-.20^{*}$ & $(.07)$ & $-.36^{* *}$ & $(.09)$ \\
\hline No qualification $^{a}$ & - & - & - & - \\
\hline Occupation (nonmanual) & .12 & $(.07)$ & .01 & $(.08)$ \\
\hline Employment (labor active) & .05 & $(.07)$ & -.06 & $(.09)$ \\
\hline \multicolumn{5}{|l|}{ School integration } \\
\hline Formally integrated & $-.77^{*}$ & $(.33)$ & -.14 & $(.29)$ \\
\hline Informally integrated & .02 & $(.09)$ & $-.47^{* *}$ & $(.14)$ \\
\hline Segregated $^{a}$ & - & - & - & - \\
\hline Constant & $-.42 * *$ & $(.15)$ & -.03 & $(.17)$ \\
\hline Nagelkerke $R$ square & .04 & & .04 & \\
\hline$(N)$ & $(4,678)$ & & $(3,220)$ & \\
\hline
\end{tabular}

Sources: Northern Ireland Referendum and Election Survey, 1998 (ARK 1998); Northern Ireland Election Study, 2003 (ARK 2003)

Note: Congruency is operationalized as 1 (congruent) and 0 (not congruent). Standard errors are in parentheses.

${ }^{a}$ omitted category of comparison

${ }^{*} p<.05 * * p<.01$ (two-tailed tests)

Multivariate analysis supports these bivariate findings (see Table 6). After a range of background variables were controlled for in the analysis, Protestants who had attended a formally integrated school were significantly less likely to hold a British-Unionist identity than those who had experienced a segregated education. A similar pattern emerges among those who had experienced an informally integrated education within the Catholic community; Catholics who had attended an informally integrated school were significantly less likely to hold both an Irish and nationalist identity than their colleagues who had attended a religiously segregated school. ${ }^{22}$ Thus, in comparison to their religiously segregated counterparts and in partial support for Hypothesis 1 in both instances, whereas the key factor in predicting Protestant attitudes is attendance at a formally integrated school, and not an informally integrated one, among Catholics the reverse is the case. Here, it is attendance at an informally integrated school, and not a formally integrated one, which emerges as the key predictor of attitudes in this instance.

To what extent are there differences in constitutional preferences when the impact of the educational sector is considered? Are individuals who have attended a formally integrated school more likely to discount traditional territorial allegiances than those who have experienced a more religiously segregated education? To address these questions, Table 7 presents

22. Alternative analysis, which denoted the formally integrated as the omitted category of comparison, lends further support to these findings. In other words, unlike their Protestant counterparts, when those who had experienced a formally integrated versus both an informally integrated or segregated education within the Catholic population were directly compared, no significant differences emerged between the various groups in relation to this issue. 
Table 7 - School Integration and Constitutional Preferences by Religious Denomination in the Adult Population in Northern Ireland

\begin{tabular}{|c|c|c|c|c|c|c|c|c|}
\hline & \multicolumn{4}{|c|}{ Protestant } & \multicolumn{4}{|c|}{ Catholic } \\
\hline & $\begin{array}{l}\text { Formally } \\
\text { Integrated }\end{array}$ & $\begin{array}{l}\text { Informally } \\
\text { Integrated }\end{array}$ & Segregated & All & $\begin{array}{l}\text { Formally } \\
\text { Integrated }\end{array}$ & $\begin{array}{l}\text { Informally } \\
\text { Integrated }\end{array}$ & Segregated & All \\
\hline & \multicolumn{8}{|c|}{ Percentages } \\
\hline United Kingdom & 65.4 & $80.8^{a}$ & $85.0^{a b}$ & 84.3 & 24.7 & 27.6 & $19.9^{b}$ & 20.6 \\
\hline United Ireland & 4.9 & 3.7 & 3.8 & 3.8 & 34.6 & 38.5 & $51.0^{a b}$ & 49.7 \\
\hline Independent NI & 6.2 & 5.9 & $3.9^{b}$ & 4.1 & 14.8 & 10.9 & 9.9 & 10.1 \\
\hline Other & 8.6 & $2.9^{a}$ & $1.6^{a b}$ & 1.8 & 2.5 & 4.5 & 2.7 & 2.9 \\
\hline Don't know & 14.8 & $6.7^{a}$ & $5.8^{a}$ & 6.0 & 23.5 & 18.6 & 16.5 & 16.8 \\
\hline Total & 100.0 & 100.0 & 100.0 & 100.0 & 100.0 & 100.0 & 100.0 & 100.0 \\
\hline \multirow[t]{2}{*}{$(N)$} & $(81)$ & $(781)$ & $(5,920)$ & $(6,782)$ & $(81)$ & $(377)$ & $(4,186)$ & $(4,644)$ \\
\hline & \multicolumn{4}{|c|}{$($ Chi-square $=52.255,8 \mathrm{df}, p<.01)$} & \multicolumn{4}{|c|}{$($ Chi-square $=34.504,8 \mathrm{df}, p<.01)$} \\
\hline
\end{tabular}

Sources: Northern Ireland Referendum and Election Survey, 1998 (ARK 1998); Northern Ireland Election Study, 2003 (ARK 2003)

Note: ${ }^{a}$ significantly different from the formally integrated at .05 level or above (two-tailed tests)

${ }^{b}$ significantly different from the informally integrated at the .05 level of above (two-tailed tests)

the breakdown in type of school by constitutional preferences for both Protestants and Catholics. Focusing initially on Protestants, Table 7 suggests some statistically significant differences among Protestants between type of school attended and constitutional preferences (Chi-square $=52.255, p<0.01$ ). Protestants who had attended an integrated school are more likely to move away from their traditional territorial allegiance-maintenance of the link with Britain-and express an undecided position than those who had experienced either an informally integrated or segregated education. The overwhelming majority of Protestants who had attended either a fairly mixed or segregated school-over 80 percent in both instances-favored retention of the union with Britain; by contrast, the equivalent proportion among those who had experienced a formally integrated education was just 65 percent.

A converse pattern emerges when those who failed to express an opinion on the issue are examined; just 6 to 7 percent of those who had experienced an informally integrated or segregated education expressed this indecisive view, compared to 15 percent among the formally integrated. Again, a notable finding is the marked unwillingness of Protestants to cross traditional allegiances in their constitutional preferences. Very few Protestants were willing to support the reunification of Ireland, or even an independent Northern Ireland for that matter, and with one exception, there were no notable differences between the various educational sectors in relation to this issue. Even among those educated in either an informal or formally integrated setting, almost no Protestant was willing to support the reunification of Ireland (less than 5 percent in both cases) and, irrespective of school background, very few (just 4 percent) were willing to endorse an independent Northern Ireland. Thus, at least as far as constitutional preferences within the adult Protestant population are concerned, our bivariate results are more or less as predicted. In support of our various hypotheses, not only are Protestants who had experienced a formally integrated education significantly different in their constitutional preferences from those who had not (partial support for Hypothesis 1) but they are also notably more likely than either the informally educated or those who had attended a segregated school to abandon traditionally established views in favor of a more neutral position or, in this instance, an indecisive view (support for Hypotheses 2 and 3).

Constitutional preferences within the Catholic population are not as clearly differentiated by educational sector, although the key distinguishing factor in this instance is attendance at an 
informally integrated school versus a segregated one. In general, Catholics who had attended an informally integrated school were significantly more likely than their religiously segregated colleagues to abandon their traditional territorial allegiance by supporting the link with Britain. Just over half of Catholics who had attended a segregated school supported the reunification of Ireland as compared to 39 percent who had attended an informally integrated school. A similar pattern emerges when the formally educated versus those who had experienced a religiously segregated education are considered. Although no statistically significant difference emerged between individuals across these two educational sectors in terms of their support for the maintenance of the union, Catholics who had attended a formally integrated school were less likely to support the reunification of Ireland than those who had attended a segregated one.

The most important finding is the willingness of Catholics to cross traditional boundaries and associate with those of the opposing territorial allegiance. Overall, just over one-fifth of Catholics support the link with Britain and a similar proportion remains undecided. Among Catholics, the results of the bivariate analysis on constitutional preferences again lend some support to our various hypotheses. Not only are Catholics who had attended an integrated school-either formal or informal-significantly different in their constitutional preferences from those who had not (Hypothesis 1) but at least as far as those who had experienced an informally integrated education are concerned they are also notably more likely to abandon traditionally established views in favor of the majority view or, in this instance, maintenance of the link with Britain (Hypothesis 5).

The multivariate analysis in Table 8 supports these findings, although the distinguishing factor for both Protestants and Catholics in this instance is prior experience of an integrated education—both formal and informal—or not. ${ }^{23}$ After a range of background variables were controlled for in the analysis, Protestants who had attended either a formally or informally integrated school were significantly less likely to support maintenance of the link with Britain than those who had experienced a segregated education. An identical, albeit converse, pattern emerges within the Catholic community; Catholics who had attended either a formally or informally integrated school were significantly more likely to abandon their traditional territorial allegiance and support retention of the link with Britain than their colleagues who had attended a religiously segregated school. Furthermore, as an inspection of the parameter estimates for both the formally integrated and informally integrated attest, this willingness to abandon traditionally established allegiances appears to be more pronounced among those who had experienced a formally integrated education than an informally integrated one.

These results on the long-term effects of integrated schooling on identity patterns and constitutional preferences in Tables 4 to 8 therefore lend support to the contact thesis and its various qualifying conditions (Hypotheses 1 to 5). This is particularly the case when constitutional preferences are considered. Individuals who attended an integrated school-either formal or informal-were not only significantly different in terms of their attitudes from those who had not (Hypotheses 1 and 2) but they were also more likely to abandon traditionally established allegiances in favor of either an intermediate (Hypothesis 3) or opposing position (Hypothesis 5), which, in the case of Catholics, represented the adoption of the majority (Protestant) community view.

Although the impact of an integrated education on identity patterns is not as clearcut, there is evidence to suggest that while the key factor in distinguishing attitudes within the Protestant community is whether or not an individual had attended a formally integrated school or not, for Catholics, it was attendance at an informally integrated school versus a

23. For the sake of parsimony in presentation, individuals who adopted a "don't know" stance in relation to this issue have been excluded from the analysis as a series of multinomial regression equations for both the Protestant and Catholic community found that school integration had no significant impact in differentiating between those who supported the union versus those who were indecisive in their views. 
Table 8 - The Impact of School Integration on Support for the Union with Britain in the Adult Population in Northern Ireland

\begin{tabular}{|c|c|c|c|c|}
\hline \multirow{3}{*}{ Sociodemographic controls } & \multicolumn{4}{|c|}{ Logistic Regression Coefficients } \\
\hline & \multicolumn{2}{|c|}{ Protestant } & \multicolumn{2}{|c|}{ Catholic } \\
\hline & & & & \\
\hline Gender (male) & -.02 & $(.09)$ & $-.37 * *$ & $(.10)$ \\
\hline Church attendance (attends) & .06 & $(.13)$ & $-.43 * *$ & $(.13)$ \\
\hline Age (years) & -.01 & $(.00)$ & $.02 * *$ & $(.00)$ \\
\hline \multicolumn{5}{|l|}{ Education } \\
\hline Tertiary & $-1.34^{* *}$ & $(.15)$ & .12 & $(.15)$ \\
\hline Secondary & $-.72 * *$ & $(.13)$ & .12 & $(.12)$ \\
\hline No qualification $^{a}$ & - & - & - & - \\
\hline Occupation (nonmanual) & .14 & $(.11)$ & .12 & $(.10)$ \\
\hline Employment (labor active) & .20 & $(.12)$ & .11 & $(.11)$ \\
\hline \multicolumn{5}{|l|}{ School integration } \\
\hline Formally integrated & $-.82^{*}$ & $(.37)$ & $.72 *$ & $(.33)$ \\
\hline Informally integrated & $-.29 *$ & $(.14)$ & $.53 * *$ & $(.15)$ \\
\hline Segregated $^{a}$ & - & - & - & - \\
\hline Constant & $2.54^{* *}$ & $(.24)$ & $-1.65^{* *}$ & $(.21)$ \\
\hline Nagelkerke $R$ square & .05 & & .03 & \\
\hline$(N)$ & $(4,582)$ & & $(2,774)$ & \\
\hline
\end{tabular}

Sources: Northern Ireland Referendum and Election Survey, 1998 (ARK 1998); Northern Ireland Election Study, 2003 (ARK 2003)

Note: The dependent variable is coded 1 (retain union with Britain) and 0 (Independent Northern Ireland/Other/United Ireland). Standard errors are in parentheses.

${ }^{a}$ omitted category of comparison

${ }^{*} p<.05 * * p<.01$ (two-tailed tests)

segregated one. More specifically, whereas Protestants who had attended a formally integrated school not only significantly differed in their attitudes from those who had not (in partial support for Hypothesis 1 and support for Hypothesis 2), they were also more likely to abandon traditional identity patterns in favor of a more neutral position (Hypothesis 3). Although the impact of integrated education on identity patterns is different among Catholics, there is again evidence to suggest that at least in comparison to their previously religiously segregated counterparts, Catholics who had experienced an informally integrated education not only held significantly different views from those who attended a religiously segregated school (in partial support of Hypothesis 1), but they were also more likely to adopt an intermediate position in relation to their identity preferences (Hypothesis 3). Finally, the significantly greater propensity among the formally integrated to abandon traditionally established identity patterns in favor of a more neutral position is an exclusively Protestant phenomenon (Hypothesis 4).

\section{Discussion}

The debate about the relationship between education and social development highlights the tension between models that emphasize the importance of education as a mirror to society and those that view education as an agent for change. This was brought into sharp relief in the United States when, following the landmark Supreme Court decision of Brown $v$ Board 
of Education, the educational system was legally identified as the institution that could initiate social change. By bringing together in the same school environment children of diverse racial and ethnic backgrounds, it was hoped that schools could transform race relations and change the "hearts and minds" of ordinary Americans. Although a similar interpretation of the role of education came later to Northern Ireland, by the 1980s, popular opinion as well as government policy had also endorsed this view. And, while support for the role of education in ameliorating racial and ethnic divisions has fallen into disfavor in the United States (see Cashin 2004), this is not the case in Northern Ireland. Opinion surveys show that not only is the current demand for places in integrated schools vastly outstripping supply, but that the vast majority of the Northern Ireland population support the further establishment of integrated schools (see Gallagher and Smith 2002).

To what extent were parents and educators correct in their assumption that integrated schools would break down religious barriers and herald in a new era in community relations and politics in Northern Ireland? While the results of our study cannot provide a definitive answer to this question, they do suggest that attendance at an integrated (both formal and informal) school have long-term benefits in weakening sectarian political outlooks and promoting a center and common ground in Northern Ireland politics, and this is particularly the case within the Protestant community.

As our results show clearly, adult Protestants who had experienced either a formally or informally integrated education were not only significantly different in their attitudes from those who had not, they were also notably more likely to abandon traditionally established views in favor of an intermediate or more neutral position in terms of both their identity patterns and constitutional preferences. The potential impact of integrated education in ameliorating sectarian divisions within the Catholic community is not as clearcut. Although Catholics who had experienced an informally integrated education were significantly more likely to adopt an intermediate position in relation to their identity preferences, this was not the case when traditionally established territorial allegiances were considered. In fact, irrespective of whether those who had experienced either a formal or informal integrated education were considered, Catholics who had attended an integrated school were significantly more likely than those who had not to not only abandon traditionally established territorial allegiances (united Ireland) but also to disavow this traditional allegiance in favor of the dominant or majority view (retention of the link with Britain). More so than any other factor, this latter finding underlines the potential tension of the political consequences of integrated education in trying to reduce intergroup conflict; one based on a shared compromise between the aspirations of the two traditions versus a reduction in division due to an acceptance of the dominant view.

These results add weight to research that suggests that contact between different racial or ethnic groups can and does affect attitudes and that it can be an important and effective tool in reducing prejudice or, in this instance, divisive and sectarian political views. However, as in more recent research on intergroup contact, our study also shows that the impact of contact varies depending on the nature of the contact situation as well as the numerical and status composition of the groups involved. Within formally integrated schools-schools where we might most expect that Allport's proposed conditions for optimal intergroup contact to be met-we find that past Protestant pupils in this instance were more likely to have moved away from their traditional identity allegiances in favor of a more overarching position. This supports Tropp and Pettigrew's (2005) majority-minority qualifying thesis, with members of the majority (Protestant) community being the most affected in terms of their views.

A similar finding emerges with respect to the proposed impact of integrated education on minority views in relation to constitutional preferences. Although, as predicted by the majorityminority qualifying theses, individuals who had been in a clear minority position at school (Catholics who had attended an informally integrated school) were significantly more likely 
than their previously religiously segregated counterparts to abandon traditionally established allegiances in favor of the majority (Protestant) community view, this was also the case among those who had attended a formally integrated school. Overall, as recently suggested by Tropp and Pettigrew (2005), one crucial and more generalized finding from this investigation is that the impact of contact may vary significantly not only in terms of the contact situation but also in terms of the social status of the groups involved. This is not to discount the possible impact of other factors-most notably the school environment-in determining both Catholic and Protestant views in this instance.

As noted earlier, no single model of integration unites Northern Ireland's integrated schools and they vary considerably with regard to how actively they promote integration. Not all staff in integrated schools have been equally proactive in achieving an integrationist ethos. In fact, previous research demonstrates that not only does considerable disparity exist among parents, teachers, and principals as to what constituted an integrated ethos within these schools, but that many teachers admit to adopting a "culture of avoidance" where politically or religiously contentious issues were either glossed over or judiciously avoided. Furthermore, there is empirical evidence to suggest that contact concerns, rather than curriculum issues, have dominated the working agenda of these schools. More importantly, as Donnelly (2006) notes, this view appears to be both shared and endorsed by the teachers themselves, with many teachers in these schools believing that as long as the school declared itself "integrated" and had roughly equal numbers of Catholic and Protestant pupils, teachers, and governors, it would, by its very nature, inculcate an ethos of tolerance and mutual understanding.

A more pronounced pattern of segregation and cultural exclusivity emerges in the informally integrated sector. Children within these religiously divided and essentially Protestant schools are not only taught by teachers drawn exclusively from the Protestant tradition but they continue to celebrate exclusively British traditions such as the singing of Protestant hymns during assembly, the laying of wreaths on Remembrance Day services, and most importantly, they also provide a pro-British curriculum as most clearly evidenced in the teaching of British history, often in a partisan and Anglo-centric manner. It is these two factors-the simplistic overreliance on contact between the two religious communities in formally integrated schools coupled with a lack of desire to proactively address issues of cultural differences via a genuinely inclusive and pluralist curriculum in both formally and especially informally integrated schools-rather than a product of their majority-minority status, which we suggest may also be a key contributing factor in determining Protestant and Catholic opinion in this instance.

The interaction between integrated education and community relations in Northern Ireland is, thus, both complex and contentious. A quarter of a century since the first integrated college was established, the benefits of integrated education in breaking down religious and cultural barriers are still disputed. The results of this study show that integrated schools are associated with the political outlooks of the pupils who attend them. Moreover, our study-based on a large sample of the adult population-suggests that the positive effects of integrated schooling extend into later life, a particularly important finding in light of U.S. findings as to the "hindsight" nature of the experiences learned in desegregated schools. As the numbers experiencing integrated schooling grows, these individuals have the potential to create a new common ground in Northern Ireland politics. As Northern Ireland attempts to transcend violent political conflict, the importance of this group who have experienced integrated education should not be underestimated. Despite the formal ratification of the Northern Ireland Agreement in 1998, and its many concerted efforts to enhance the center ground in politics, more recent research suggests that Northern Ireland has become more, not less, religiously divided in the post-Agreement period, especially in relation to electoral behavior and party preferences (see Hayes, McAllister, and Dowds 2005). 
Intergroup contact, even when formally endorsed within an educational setting, should not be considered the only "cure" for prejudice and ethnic division. This is particularly the case when deeply divided and polarized societies such as Northern Ireland are investigated. Intergroup contact via integrated schooling alone cannot be expected to tackle the mutually reinforcing problems of segregation, disadvantage (real and perceived), divergent political aspirations as well as the pervasive "them" and "us" mentality that continue to inform intercommunity relations within this society (Hayes and McAllister 2004; Hughes and Donnelly 2002; Hughes et al. 2006). The results of this investigation suggest that intergroup contact via an integrated education system is not only a fruitful place to start, but it should also be one key element within a wider strategy for addressing ethnic and/or racial divisions within this and other societies who have experienced similar levels of ethno-political conflict.

This study has some important methodological limitations. First, given the cross-sectional nature of our data, there remains the question of the direction of causality. In the absence of longitudinal data, we cannot provide a definitive answer to this question, however, the weight of academic opinion supports our interpretation, namely, that contact through an integrated school setting leads to less sectarian political outlooks. Second, our measures of exposure to integrated education are rudimentary; we do not know for how long individuals attended a formally integrated school and what, if any, particular mechanisms were put in place by teachers and school authorities to foster an "integrationist" ethos. In fact, contrary to the Tropp and Pettigrew (2005) minority-majority thesis, it could be argued that the adoption of the majority (Protestant) constitutional view among Catholics who had attended either a formally or informally integrated school may be due to the pro-British nature of the school environment rather than a product of their minority status. A similar lack of information emerges in relation to individuals who attended an informally integrated school; we do not know how long students attended these schools; what exactly the religious balance in these schools was; and, more importantly, what efforts, if any, were made by teachers and the school authorities to accommodate their minority status.

Resolving these methodological limitations and evaluating their theoretical consequences should be a future research priority. Future research should critically examine the role of integrated education in promoting more integrationist views among the general adult population and, where possible, utilize panel data. Only via a longitudinal approach can definite conclusions be drawn about the causal effects of integrated education on identities, attitudes, and behavior. This research should also consider integrated education as part of the broader educational system in Northern Ireland and its impact on tolerance and discrimination in Northern Ireland. This would include comparisons not only with adults who had attended segregated schools, but also those who claimed to have had some cross-community contact, albeit within an informally integrated setting. As our research on national identity patterns also demonstrates, among adult Catholics at least, it is the presence of members of the other religious community in an informally integrated setting rather than a formally integrated school per se, which leads to less sectarian views.

In order to assess the influence of parents as well as the nature of the actual contact situation, future research should not only include the opinions and sociodemographic background characteristics of parents but also investigate the degree to which these various educational settings-integrated, informally integrated, and segregated schools-facilitate or inhibit the promotion of nonsectarian views. A key component of this investigation should include a detailed analysis of both the nature and content of the curriculum with particular emphasis on the degree to which it identifies and promotes one cultural tradition-British versus Irish, unionist versus nationalist-at the expense of the other. This examination should not only include a detailed examination of the various subjects taught but also the overall political content of the curriculum particularly in terms of the teaching of religious studies as well as politics and history. A detailed investigation of this issue is particularly important in the light of previous research as to the diverse nature of integrated schools in 
Northern Ireland as well as the views of religious authorities, most notably the Catholic Church, which continues to maintain that their schools are just as well placed as integrated ones to promote reconciliation and foster less sectarian views with this society (Catholic Bishops of Northern Ireland 2001) despite an insistence that maintaining a Catholic ethos is, in their view, central to school life.

Finally, a detailed examination of the religious balance within the schools should also be taken into account. This is particularly the case when Protestants in established Catholic schools are considered. As our research demonstrates, not only were Catholics who attended informally integrated (established Protestant) schools more likely to adopt an intermediate stance in relation to their national identity but they were also significantly more likely to disavow traditional territorial allegiances. To what extent are the views of Protestants similarly affected in established Catholic schools? Or, contrary to their Catholic counterparts, does their majority status within society impede the dissolution of traditionally established sectarian attitudes even in situations where they are a numerical minority? Only via a detailed investigation of this issue for both religious communities will the mediating impact of majority-minority relations on political outlooks within these various educational settings be comprehensively understood.

Despite the methodological challenges this paper leaves to future research, it is important to remember its primary contribution: to assess the impact of integrated education on political identities. Using contact theory as our explanatory framework, the primary purpose of the investigation was to assess whether or not individuals from the Catholic and Protestant communities in Northern Ireland who attended an integrated-either formal or informalschool were less sectarian in their political outlooks than those who attended a religiously segregated one. While much has been written about the impact of intergroup contact on reducing racial prejudice, to date its impact in terms of ameliorating political divisions has not been systematically assessed. It is to an investigation of this issue-the long-term impact of intergroup contact on political identities-that future research should be directed. As this investigation demonstrates, not only should these studies focus on the potentially important mediating influence of majority-minority relations within the contact situation but, where possible, the comparative influence of other interactive settings, as well as a detailed study of the school environment, should also be assessed. Contrary to minority-majority thesis, it could be argued that a key factor in accounting for both Protestant and Catholic views in this instance may not be so much due to their differential status in a contact situation but rather derive from the absence of a genuinely pluralist and diverse environment within a school setting. Thus, it is to an assessment of these two competing explanations-intergroup contact versus the school environment-in determining political outlooks that future research should be directed.

\section{References}

Abbott, Lesley, Seamus Dunn, and Valerie Morgan. 1998. Integrated Education in Northern Ireland: An Analytical Review. Ulster, Northern Ireland: University of Ulster, Center for the Study of Conflict.

Access Research Knowledge (ARK). 1998-2003. Northern Ireland Life and Times Survey. Retrieved February 27, 2004 (www.ark.ac.uk/nilt/datasets/).

- 1998. Northern Ireland Referendum and Election Survey. Retrieved February 27, 2004 (www. ark.ac.uk/sol/surveys/electoral_studies/NIES/1998/website/).

—. 2003. Northern Ireland Election Study. Retrieved February 27, 2004 (www.ark.ac.uk/sol/surveys/ electoral_studies/NIES/2003/website/).

Allport, Gordon W. 1954. The Nature of Prejudice. Cambridge, MA: Addison Wesley.

Breen, Richard and Bernadette C. Hayes. 1996. "Religious Mobility in the United Kingdom." Journal of the Royal Statistical Society, Series A 159:493-504. 
Breen, Richard and Paula Devine. 1999. "Segmentation and the Social Structure." Pp. 52-65 in Politics in Northern Ireland, edited by Paul Mitchell and Rick Wilford. Boulder, CO: Westview Press.

Brown v. Board of Education of Topeka, Kansas. 1954. 347 U.S. 483, 74S.Ct. 686, 98 L.Ed. 873.

Cashin, Sheryll. 2004. The Failures of Integration: How Race and Class are Undermining the American Dream. New York: Public Affairs.

Catholic Bishops of Northern Ireland. 2001. Building Peace, Shaping the Future. Armagh, Northern Ireland: Ara Coeli.

Civil Rights Project. 2002. The Impact of Racial and Ethnic Diversity on Educational Outcomes. Cambridge, MA: Harvard University.

Cook, Stuart W. 1978. "Interpersonal and Attitudinal Outcomes in Cooperating Interracial Groups." Journal of Research and Development in Education 12:97-113.

Darby, John. 1974. "History in the Schools: A Review Article." Community Forum 4:37-42.

1976. Conflict in Northern Ireland: The Development of a Polarized Community. Dublin, Ireland: Gill and Macmillan.

Darby, John, Dominic Murray, D. Batts, Seamus Dunn, Sean Farren, and J. Harris. 1977. Education and Community in Northern Ireland: Schools Apart? Coleraine, Northern Ireland: The New University of Ulster.

Department of Education of Northern Ireland (DENI). 2005. Pupil Religion Series: Table 6b. Retrieved June 10, 2006 (http://www.deni.gov.uk/pupil_religion_series_cleared-5.xls).

Dixon, Jeffrey C. and Michael S. Rosenbaum. 2004. "Nice to Know You? Testing Contact, Cultural, and Group Threat Theories of Anti-Black and Anti-Hispanic Stereotypes." Social Science Quarterly 85:257-80.

Donnelly, Caitlin. 2004a. "Constructing the Ethos of Tolerance and Respect in an Integrated School: The Role of Teachers." British Educational Research Journal 30:263-78.

— 2004b. "What Price Harmony? Teachers' Methods of Delivering an Ethos of Tolerance and Respect for Diversity in an Integrated School in Northern Ireland." Educational Research 46:3-16.

- 2006. "The Pluralist Ethos In Integrated Schools: A Contested Concept?" Pp. 172-82 in Devolution and Pluralism in Education in Northern Ireland, edited by Caitlin Donnelly, Penny McKeown, and Bob Osborne. Manchester, UK: Manchester University Press.

Donnelly, Caitlin and Joanne Hughes. 2006. “Contact, Culture and Context: Evidence from Mixed Faith Schools in Northern Ireland and Israel." Comparative Education 42:493-516.

Dunn, Seamus 1986. "The Role of Education in the Northern Ireland Conflict." Oxford Review of Education $12: 233-42$.

Dunn, Seamus, John Darby, and Kenneth Mullan. 1991. Schools Together? 2d ed. Coleraine, Northern Ireland: University of Ulster, Center for the Study of Conflict.

Dunn, Seamus and Valerie Morgan. 1991. "The Social Context of Education in Northern Ireland." European Journal of Education 6:179-90.

1999. “A Fraught Path-Education as a Basis for Developing Improved Community Relations in Northern Ireland." Oxford Review of Education 25:141-53.

Eaton, Susan E. 2001. The Other Boston Busing Story: What's Won and Lost Across the Boundary Line. New Haven, CT: Yale University Press.

Fahey, Tony, Bernadette C. Hayes, and Richard Sinnott. 2006. Conflict and Consensus: A Study of Attitudes and Values in the Republic of Ireland and Northern Ireland. Boston: Brill.

Farren, Sean. 1976. "Culture and Education in Ireland." Compass: The Journal of the Irish Association for Curriculum Development 5:25-35.

Gallagher, A. M. 1995. Majority Minority Review 1 Education in a Divided Society: A Review of Research and Policy. $2 \mathrm{~d}$ ed. Coleraine, Northern Ireland: University of Ulster.

Gallagher, Tony. 2003. 'Education and Equality in Northern Ireland.' Pp. 59-83 in Researching the Troubles: Social Science Perspectives on the Northern Ireland Conflict, edited by Owen Hargie and David Dickson. London, UK: Mainstream. 2004. Education in Divided Societies. Basingstoke, UK: Palgrave.

Gallagher, Tony and Alan Smith. 2002. "Attitudes to Academic Selection, Integrated Education, and Diversity Within the Curriculum." Pp. 120-37 in Social Attitudes in Northern Ireland: The Eighth Report, edited by Ann Marie Gray, Katrina Lloyd, Paula Devine, Gillian Robinson, and Deirdre Heenan. London, UK: Pluto.

Gallagher, Tony, Alan Smith, and Alison Montgomery. 2003. Integrated Education in Northern Ireland: Participation, Profile, and Performance. Coleraine, Northern Ireland: UNESCO Center, University of Ulster. 
Hayes, Bernadette C. and Ian McAllister. 1999a. "Ethnonationalism, Public Opinion, and the Good Friday Agreement." Pp. 30-48 in After the Good Friday Agreement: Analysing Political Change in Northern Ireland, edited by Joseph Ruane and Jennifer Todd. Dublin, Ireland: University College Dublin Press. . 1999b. "Generations, Prejudice, and Politics in Northern Ireland." Pp. 457-91 in Ireland North and South: Perspectives from Social Science, edited by Anthony F. Heath, Richard Breen, and Christopher T. Whelan. Oxford, UK: Oxford University Press.

2001. "Sowing Dragon's Teeth: Public Support for Political Violence and Paramilitarism in Northern Ireland." Political Studies 49:901-22.

2004. "Protestant Disillusionment with the Northern Ireland Peace Agreement." Irish Journal of Sociology 13:109-25.

Hayes, Bernadette C., Ian McAllister, and Lizanne Dowds. 2005. “The Erosion of Consent: Protestant Disillusionment with the 1998 Northern Ireland Agreement." Journal of Elections, Public Opinion, and Parties 15:147-67.

Hewstone, Miles. 2003. "Intergroup Contact: Panacea for Prejudice?" The Psychologist 16:352-55.

Holme, Jennifer Jellison, Amy Stuart Wells, and Anita Tijerina Revilla. 2005. "Learning Through Experience: What Graduates Gained by Attending Desegregated High Schools." Equity $\theta$ Excellence in Education 38:14-24.

Hughes, Joanne. 2003. "Resolving Community Relations Problems in Northern Ireland: An Intra-Community Approach." Research in Social Movements, Conflict, and Change 24:257-82.

Hughes, Joanne, Andrea Campbell, Miles Hewstone, and Ed Cairns. 2006. “Segregation in Northern Ireland: Implications for Community Relations Policy." Unpublished manuscript.

Hughes, Joanne and Caitlin Donnelly. 2002. "Ten Years of Social Attitudes in Community Relations in Northern Ireland." Pp. 39-56 in Social Attitudes in Northern Ireland: The Eighth Report, edited by Ann Marie Gray, Katrina Lloyd, Paula Devine, Gillian Robinson, and Deirdre Heenan. London, UK: Pluto.

Irwin, Colin. 1991. Education and the Development of Social Integration in Divided Societies. Belfast, Northern Ireland: Department of Social Anthropology, Queen's University.

Magee, James. 1970. "The Teaching of Irish History in Irish Schools." The Northern Teacher 10:15-21.

McClenahan, Carol, Ed Cairns, Seamus Dunn, and Valerie Morgan. 1996. "Intergroup Friendships: Integrated and Desegregated Schools in Northern Ireland." Journal of Social Psychology 136:549-58.

McGarry, John and Brendan O'Leary. 1995. Explaining Northern Ireland: Broken Images. Oxford, UK: Blackwell.

McGlynn, Claire. 2003. "Integrated Education in Northern Ireland in the Context of Critical Multiculturalism." Irish Educational Studies 22:1-28.

McGlynn, Claire, Ulrike Niens, Ed Cairns, and Miles Hewstone. 2004. “Moving Out of Conflict: The Contribution of Integrated Schools in Northern Ireland to Identity, Attitudes, Forgiveness, and Reconciliation." Journal of Peace Education 1:147-63.

McGrath, Michael. 2000. The Catholic Church and Catholic Schools in Northern Ireland. Dublin, Ireland: Irish Academic Press.

Montgomery, Alison, Grace Fraser, Claire McGlynn, Alan Smith, and Anthony Gallagher. 2003. Integrated Schools in Northern Ireland: Integration in Practice. Coleraine, Northern Ireland: University of Ulster, UNESCO Center.

Morgan, Valerie and Grace Fraser. 1999. “When Does 'Good News' Become 'Bad News'? Relationships between Government and the Integrated Schools in Northern Ireland." British Journal of Educational Studies 47:364-79.

Moxon-Browne, Edward. 1991. "National Identity in Northern Ireland." Pp. 23-30 in Social Attitudes in Northern Ireland, edited by Peter Stringer and Gillian Robinson. Belfast, Northern Ireland: Blackstaff.

Murray, Dominic 1985. Worlds Apart: Segregated Schools in Northern Ireland. Belfast, Northern Ireland: Appletree Press.

Niens, Ulrike, Ed Cairns, and Miles Hewstone. 2003. "Contact and Conflict in Northern Ireland." Pp. 123-39 in Researching the Troubles: Social Science Perspectives on the Northern Ireland Conflict, edited by Owen Hargie and David Dickson. London, UK: Mainstream.

Northern Ireland Council for Integrated Education (NICIE). 2004a. IE Movement: Taking the Fear out of Difference. Retrieved September 20, 2005 (www.nicie.org/aboutus/default.asp?id=25). . 2004b. What is Integrated Education? Retrieved September 20, 2005 (www.nicie.org/aboutus/default. asp?id=30).

2005. Annual Report 04-05. Retrieved September 20, 2005 (www.nicie.org/publications/default. asp?type=archived). 
O'Connor, Fionnuala. 2002. A Shared Childhood: The Story of Integrated Schools in Northern Ireland. Belfast, Northern Ireland: Blackstaff Press.

Office of the First Minister and Deputy First Minister (OFMDFM). 2005. A Shared Future. Belfast, Northern Ireland: Stormont.

Pettigrew, Thomas F. 1997. "Generalized Intergroup Contact Effects on Prejudice." Personality and Social Psychological Bulletin 23:173-85. 1998. "Intergroup Contact Theory." Annual Review of Psychology 4:65-85.

Pettigrew, Thomas F. and Linda R. Tropp. 2000. “Does Intergroup Contact Reduce Prejudice?: Recent Meta-Analytic Findings." Pp. 93-1 14 in Reducing Prejudice and Discrimination, edited by Stuart Oskamp. Mahwah, NJ: Lawrence Erlbaum.

. 2006. "A Meta-Analytic Test of Intergroup Contact Theory." Journal of Personality and Social Psychology $90: 751-83$.

Ruane, Joseph and Jennifer Todd. 1996. The Dynamics of the Conflict in Northern Ireland. Cambridge, UK: Cambridge University Press.

Russell, Raymond. 2004. "Employment Profiles of Protestants and Catholics: A Decade of Monitoring." Pp. 24-48 in Fair Employment in Northern Ireland: A Generation On, edited by Bob Osborne and Ian Shuttleworth. Belfast, Northern Ireland: Blackstaff Press.

Schofield, Janet Ward. 1995. "Review of Research on School Desegregation's Impact on Elementary and Secondary School Students." Pp. 597-617 in Handbook of Research on Multicultural Education, edited by James A. Banks and Cherry A. McGee Banks. New York: McMillan.

Smith, Alan. 2001. "Religious Segregation and the Emergence of Integrated Schools in Northern Ireland." Oxford Review of Education 27:559-75.

Stringer, Maurice, Ronnie Wilson, Paul Irwing, Melanie Giles, Carol McClenahan, and L. Curtis. 2000. The Impact of Schooling on the Social Attitudes of Children. Belfast, Northern Ireland: The Integrated Education Fund.

Trew, Karen. 1986. “Catholic-Protestant Contact in Northern Ireland." Pp. 93-106 in Contact and Conflict in Intergroup Encounters, edited by Miles Hewstone and R. Brown. Oxford, UK: Basil Blackwell.

Tropp, Linda R. and Thomas F. Pettigrew. 2005. "Relationships between Intergroup Contact and Prejudice among Minority and Majority Status Groups." Psychology Science 16:951-57.

Wells, Amy Stuart, Jennifer Jellison Holme, Anita Tijerina Revilla, and Awo Korantemaa Atanda. 2005. How Desegregation Changed Us: The Effects of Racially Mixed Schools on Students and Society. Retrieved July 23, 2005 (http://cms.tc.colunbia.edu/i/a/782_ASWells041504.pdf).

Wells, Amy Stuart and Robert L. Crain. 1994. "Perpetuation Theory and the Long-Term Effects of School Desegregation." Review of Education Research 64:531-55.

Williams, R. 1947. Reduction of Intergroup Tension. New York: Social Science Research Council.

Zirkel, Sabrina and Nancy Cantor. 2004. "Fifty Years after Brown v. Board of Education: The Promise and Challenge of Multicultural Education." Journal of Social Issues 60:1-15. 